\title{
THEORIZING IN THE ABSENCE OF A THEORY: The Case of the Aramaic Targums to the Pentateuch
}

\author{
Simon Lasair, \\ University of Alberta
}

\section{INTRODUCTION}

The Hebrew noun targum is often translated as "translation". Within the literature of early Judaism (c. 200-800 CE) targum can refer to the Greek translation of the Hebrew Bible, also known as the Septuagint, the Aramaic (another Semitic language) portions of the Hebrew Bible, or a certain kind of Aramaic translation of the Hebrew Bible (Sokoloff Palestinian 590-91, Sokoloff Babylonian 1231, Smelik "Language" 201-5). It is this last body of literature, the Aramaic Targums, that I will discuss in this paper. Although the Aramaic Targums never use the noun targum or the related verb le-tirgem to describe their relationship with the Hebrew Bible, the targums are a kind of translation literature. Typically, targum scholars have used the term "translation" to describe only parts of the targums - the one-to-one inter-linguistic rendering of the Hebrew Bible text into Aramaic-since some targums also add significant portions of narrative material to their translations. Yet from my perspective these added portions are no less translational than the one-to-one inter-linguistic rendering of the Hebrew Bible that is one of the defining features of the targums to the Pentateuch (the first five books of the Hebrew Bible).

Matters are further complicated by the fact that within the context of early Jewish literature there are no detailed descriptions concerning how to produce a targum or what qualifies as a "good" targum. As a result, modern targum scholars are forced to theorize about the basic translational principles governing targum production without any guidance from the targum producers themselves - theorizing in the absence of a theory. In this paper I will argue that there are three features of the targumic genre, in particular the Targums to the Pentateuch that should figure prominently in the task of theorization. They are: 1) the targumic shadow of the Hebrew Bible; 2) the translational function of the targumic narrative expansions; and 3) the large-scale coherence structures 
present in the targums that are absent from the Hebrew Bible. By focusing on these three features it will become apparent that the Pentateuch Targums are engaged in a significant project of cultural appropriation, updating and transforming the biblical narratives for the sake of a post-biblical early Jewish audience. The Pentateuch Targums thus provide interesting examples of translation in an ancient context, insofar as they reinforce the problematic status of the term "translation" in modern translation studies literature. They furthermore demonstrate some of the cultural and counter-cultural aspects of translation that translation scholars are beginning to explore in a more deliberate and sustained way. Targumic literature may therefore teach modern translation scholars much, both about the history of translation, and also about some of the conceptual problems that attend translation in several different social and historical contexts.

\section{The TaRgumic Shadow OF THE Biblical TeXT}

Alexander Samely was the first to use the term "targumic shadow" in reference to the relationship between the Pentateuch Targums' Aramaic texts and the text of the Hebrew Bible ("Writing" 182-85). In short the targumic shadow refers to the one-to-one correspondence between the Hebrew Bible text and the target targumic text. This one-to-one correspondence includes close syntactic imitation and lexematic similarity. Where there is one word in the Hebrew Bible text there is a corresponding word in the targum text. And often the targumic word has the same tri-consonantal lexical root as the Hebrew Bible word, as well as the same morphology, insofar as inter-linguistic transfer between biblical Hebrew and targumic Aramaic will allow. Take for example the Hebrew Bible version of Genesis 22:1 (this is the first verse of the aqedah narrative, or the binding of Isaac story) compared with the Targum Onqelos version (my transliteration and translation unless otherwise indicated. The translation of the Hebrew Bible verse is based on the consonantal text of the Biblica Hebraica Stuttgartensia and the translation of Targum Onqelos_is based on consonantal text found in the Sperber edition of this targum):

\begin{tabular}{|c|c|}
\hline Hebrew Bible & Targum Onqelos \\
\hline 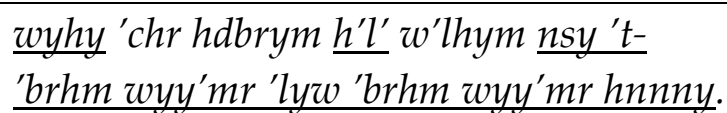 & 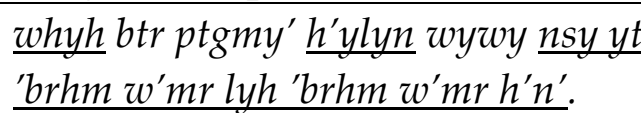 \\
\hline After these things God tested & After these things the Lord tested \\
\hline
\end{tabular}

(C) Copyrights TranscUlturAl \& Author (2009) 
\begin{tabular}{|l|l|}
\hline Abraham. And he said to him, & Abraham. And he said to him, \\
"Abraham". And he said, "Here I am". & "Abraham". And he said, "Here I am". \\
\hline \hline
\end{tabular} Fig. 1 Comparison of Hebrew Bible and Targum Onqelos Genesis 22:1

The underlined portions of the transliteration and translation indicate where there is a common lexical root shared by the Hebrew Bible and the targum. Admittedly the shared words are often common names (e.g. Abraham), yet it is worth noting the difference in divine name used between the Hebrew Bible and the targum. It is also important to note that the targum has represented the Hebrew Bible's accusative marker ' $t$ with the Aramaic $y t$, since in targumic Aramaic the accusative marker is an unnecessary case indicator. This strict adherence to both lexematic and syntactic imitation is one of the defining features of the Pentateuch Targum genre, as I mentioned already. In fact, this "shadowing" has been called the basis of the targumic translation technique. However, early Jewish literature says little about this phenomenon. The earliest collection of rabbinic Jewish law, the Mishnah (ca. 200 CE), does mention translation, but only concerns itself with how translations should be delivered in the context of the synagogue in conjunction with the liturgical reading of the Hebrew Bible (Mishnah Megillah 4:4). This being stated, most targumic manuscripts contain the first few words of the corresponding Bible verse in Hebrew, reinforcing the idea that the Aramaic was always accompanied both in a written and oral context by at least a portion of the Hebrew source text (Smelik "Orality" 49-81). Although some of the other Pentateuch Targums (there are two other complete targums to the Pentateuch: Targum Neofiti and Targum PseudoJonathan) are not as exacting in their imitation of the Hebrew as is Targum Onqelos, they still make an effort to maintain some sort of one-to-one correspondence between the Hebrew Bible text and the target targumic narrative. This tendency would have had several concrete effects for those who received the targumic narratives.

First, the lexematic and syntactic similarity between the Hebrew Bible and the targum text would have allowed the targums' readers/audiences to follow the progression of the Hebrew Bible narrative as if they were reading or hearing the Hebrew Bible itself, assuming that the targums as translations were performed in the synagogue context as the Mishnah seemingly indicates. However, the Mishnah reference is ambiguous since it uses the Hebrew word meturgeman, which can refer to both a translator (cf. Neusner's translation) as 
well as to one who recites the targum. From this oblique reference it is impossible to determine whether the framers of the Mishnah are envisioning the phenomenon of Targum at this point or not. Nevertheless, the lexematic and syntactic similarity between the targums and the Hebrew Bible would furthermore create the possibility of blurring the distinction between the Hebrew Bible and targumic narratives when the two differed. Although the differences between the two may have been emphasized by the reading practices of the synagogue (Fraade 253-86), there is no evidence to suggest that there were strong social institutions established outside the synagogue for the purpose of reinforcing the differences between the Bible and its various targums. In the case of some targums the differences between the source and target texts are substantial enough to significantly change the dynamics of the narratives being presented in the targum texts. Yet due to the constant imitation of the biblical text in the targumic context, the targumic narratives and the biblical narrative could have become confused to the extent that the two may have been indistinguishable in the minds of some readers or hearers. And all this would have been aided and facilitated by the targumic shadow of the biblical text. Again there is no explicit theory from the ancient context discussing this dynamic. Most modern scholars derive their comments on this topic from fragmentary and ambiguous evidence such as that provided by the Mishnah (cf. e.g. Smelik "Rabbinic").

Nevertheless, the targumic shadow of the biblical text plays another role in structuring the targumic narratives. By maintaining such a close lexical and syntactic relationship with the Hebrew Bible-even when there are differencesthe targums would have ensured that some of the macro-structures of the Hebrew Bible narrative would have been brought into the Aramaic context. As with the close imitation of the Hebrew Bible's micro-structures, this transference of biblical macro-structures into the targumic context goes unmentioned in the ancient sources. The precise dynamics of this phenomenon will become evident in the next section when I examine the translational function of the targumic narrative expansions. To anticipate the argument of that section, the targumic shadow of the biblical text provided a framework into which the framers of the targums could insert their narrative expansions (Samely "Scripture's Segments" 107-15). This framework, or macro-structure, remained more or less intact in the targums, which meant that the broad details of the Hebrew Bible narrative were communicated in Aramaic. Yet once the targums introduced their changes, some 
of the finer details of this narrative became enhanced, or at least received a nuance that was not communicated in the Hebrew Bible, at least not explicitly. The targumic shadow of the Hebrew Bible therefore also served as a control on what could or could not be added by the framers of the targums. There was a great deal of liberty granted these individuals and groups, as we shall see below, but all new narrative material had to somehow fit within the pre-existing framework established by the Hebrew Bible. This is even more the case if we agree with the widely held hypothesis that the targum was performed in the synagogue to make the Hebrew Bible narratives accessible to audiences that would otherwise not understand it (Greenspahn 179-95). This performative setting would have necessitated that the performers of the targums (meturgemanim) not stray too far from the Hebrew Bible narrative lest the crucial connection between Bible and targum be lost (Mishnah Megillah 4:4 is the usual proof-text used to substantiate the existence of this practice). The targumic shadow of the Hebrew Bible is that which simultaneously makes targumic additions to the biblical narrative possible, but which also safeguards the larger structures of that same narrative. It is this formal paradox that is characteristic of the Pentateuch Targum genre. Any attempt to describe the targumic genre must account for this dynamic in one way or another, regardless of whether we posit an oral or written context in which the targums were used (given that the only evidence we have for targumic activity is written, there is much discussion in the field of targum studies as to how aspects of orality may have been incorporated into written targumic texts. Cf. Smelik "Orality").

\section{The Translational Function of the Targumic NarRative Expansions}

Targumic narrative expansions are what I have been referring to so far as the portions of narrative added by the targums to their translations of the Hebrew Bible. Of the complete Pentateuch Targums, Targum Onqelos is the least expansive, Targum Pseudo-Jonathan is the most expansive, being nearly twice the length of Targum Onqelos, and Targum Neofiti lies between the two in terms of its amount of added content. There is some overlap between the added portions in Targums Pseudo-Jonathan and Neofiti, suggesting a common source for both. Furthermore, scholars have suggested that an early form of Targum Onqelos formed the basis of the one-to-one inter-linguistic renderings of Targums Neofiti and Pseudo-Jonathan (Flesher). In terms of the narrative expansions, often their origins can be explained by uncovering a specific hermeneutical maneuver 
behind them-more on this shortly. But when examining the targums from a translation perspective these hermeneutical maneuvers only provide partial explanations for the dynamics that can be detected in the targumic narratives. It is also important to discuss some of the inter-cultural dynamics that may have played a role in the production of the narrative expansions, since they are just as much a part of translation as are some of the inter-linguistic phenomena discussed in the previous section. To date the inter-cultural aspects of the targumic translation techniques have been downplayed by targum scholars. However, some of these inter-cultural dynamics are best illustrated by discussing the Targum Pseudo-Jonathan version of Genesis 22:1. Here it is in English translation (this translation is based upon the Clarke edition of Targum PseudoJonathan):

After these things when Isaac and Ishmael quarreled. Ishmael said, "To me it is fitting that I should inherit my father for I am his firstborn son." And Isaac said, "To me it is fitting to inherit my father because I am the son of Sarah his wife, whereas you are the son of Hagar the maidservant of my mother." Ishmael answered and said, "I am more worthy to inherit than you because I was circumcised at thirteen years, and if it was my will to refuse I would not have handed myself over to be circumcised. But you were circumcised at eight days. If you had had knowledge, perhaps you would have not handed yourself over to be circumcised." Isaac replied and said, "Look, today I am thirty-seven years old. If the Holy One, Blessed be He, were to request all my limbs, I would not refuse." Immediately these words were heard before the Master of the World, and immediately the Memra of the Lord tested Abraham. And he said to him, "Abraham". And he said to him, "Here I am".

As with the translation of Targum Onqelos above I have underlined the portions of this passage which are a one-to-one rendering of the Hebrew Bible verse. Obviously Pseudo-Jonathan's version differs significantly from the strict one-toone rendering of Targum Onqelos. Part of what makes Pseudo-Jonathan's narrative expansion possible is the semantic ambiguity of the Hebrew word hdbrym which is translated by the targum with the Aramaic word ptgmy'. In both cases the Hebrew and Aramaic words can mean "words", "matters", or "things". Often in the Hebrew Bible narrative the formula wyhy 'chr hdbrym h'lh ("After these things ...") is used to indicate the passage of time. Yet in many cases the referent of the words hdbrym h'lh ("these things") is ambiguous. Sometimes the targums resolve the ambiguity by indicating chronological proximity between the episodes for which this phrase is a transition marker (cf. e.g. Targum Neofiti and Targum Pseudo-Jonathan's rendering of Genesis 15:1). In the case of Genesis 22:1 Targum 
Pseudo-Jonathan has understood the Hebrew word hdbrym to mean "words" and has therefore created the dispute between Ishmael and Isaac, the two sons of Abraham. The "words" after which the events of this chapter take place are the "words" of Ishmael and Isaac. These are some of the hermeneutical dynamics that have influenced the production of this passage. Again there is no discussion concerning this kind of targumic hermeneutical move in the available ancient sources. The conceptual tools I have used to describe it are exclusively the products of modern scholarship. This hermeneutical move plays no small part in the process of translational cultural appropriation I will describe below.

The inter-cultural dynamics I mentioned before are twofold. First, the interpretation of the Hebrew hdbrym as "words" in this passage is one that is common in early Jewish literature (cf. e.g. Genesis Rabbah 55:4 translated in Samely Forms 214). It is therefore not surprising that this interpretation should appear in this context. Not only would this interpretation have been familiar to early Jews, but it would have also provided an adequate and perhaps even authoritative interpretation of the Hebrew word hdbrym. However, what might be more significant in this regard is the fact that Targum Pseudo-Jonathan probably received its final redaction sometime after the Muslim conquest of the Near East (for discussion on the date of Pseudo-Jonathan see Shinan, Hayward). This is usually argued on the basis of Pseudo-Jonathan's rendering of Genesis 21:21 where Ishmael is said to marry both Adisha and Fatima, also known as the prophet Mohammad's wife and daughter. Since all Arabs, and, by default, Muslims were considered by early Jews to be the children of Ishmael, the dispute in Genesis 22:1 can be seen as an argument between Muslims and Jews concerning who is most worthy to inherit Abraham's legacy, given that Abraham is considered to be the father of both Jews and Muslims. From the targum's perspective it is obvious that Isaac should be considered the most worthy heir, not only due to his pious outburst in 22:1, but also due to his willingness to ensure that he is sacrificed properly (in Pseudo-Jonathan's version of Genesis 22:10 Isaac instructs Abraham to bind him tightly to ensure the validity of their sacrifice, and Isaac furthermore stretches forth his neck to aid Abraham in the act of ritual slaughter). As a result, Targum Pseudo-Jonathan's version of Genesis 22:1, indeed the entirety of Genesis 22, can be seen to have an apologetic function, insofar as it focuses on the issue of Isaac's righteousness and worthiness to be Abraham's only heir. In a cultural environment where Muslims and Jews were coming into contact and potential conflict, passages such as these would have played an 
important role in justifying and protecting the boundaries around Jewish communities. Given this cultural setting, it would appear as if the targum has appropriated the biblical narrative to address concerns that were present in the targum's own time period - a translational move that is employed by some modern as well as ancient translators (Baker 96-98). In other words, the targum has transformed the biblical narrative into something that would have greater cultural currency for its target audience than if it left the source narrative as it was in the Hebrew Bible.

\section{CoHerence Structures}

I have already alluded to this aspect of targumic translation techniques by introducing Targum Pseudo-Jonathan's rendering of Genesis 22:10 into the discussion of the previous section. In short, the move wherein Pseudo-Jonathan 22:1 transforms the aqedah narrative into an apologia for Isaac's worthiness to become Abraham's heir is sustained and substantiated throughout the entirety of Pseudo-Jonathan's rendering of Genesis 22. This becomes especially evident in 22:10, which is the crucial moment in the episode. Abraham has been commanded by God to slaughter Isaac, and Isaac has vowed that if God were to demand his entire body in sacrifice he would not withhold it. Genesis 22:10 narrates the moment when Abraham lifts his knife to slaughter Isaac, and, according to the targum, Abraham does not hesitate, and furthermore Isaac helps his father by instructing Abraham to bind him tightly; Isaac also stretches forth his neck so Abraham can slaughter him with a single knife stroke-a crucial component to Jewish acts of ritual slaughter. The targum additionally states that both these actions and attitudes are noticed by angels, who are understood in the targumic narratives as reliable witnesses of what they observe. As such, the righteousness of both Abraham and Isaac is affirmed by heavenly sources, a subtle yet effective narrative device used to prevent readers or hearers from drawing different conclusions.

This strong coherence in the targumic narrative makes up for an overwhelming ambiguity in the Hebrew Bible narrative. This ambiguity has been much commented upon both in ancient and modern times, Søren Kierkegaard being one of the most famous modern commentators. What strikes most commentators is the stunning silence of the biblical narrative concerning Abraham's thoughts during this episode (Auerbach ch. 1). Even God's seeming

(C) Copyrights TransculturAl \& Author (2009) 
ambivalence toward Isaac's life at the beginning of the chapter is considered problematic (cf. Genesis 22:2). Nevertheless, this chapter has played an important role in both Judaism and Christianity, insofar as God's sparing of Isaac at the last minute and God's provision of a different yet suitable offering (Genesis 22:12) forms the basis of sacrificial theology for both Jews and Christians. This later justification for Jewish cultic practices and Christian beliefs concerning Jesus' crucifixion, which is the product of generations of interpretation, however, does little to erase the concrete theological and narrative problems in the episode itself. Even in modern times this episode is considered problematic among biblical scholars (LaCocque and Ricoeur). Targum Pseudo-Jonathan, however, in its updating of the narrative, and in its several narrative expansions, goes part of the way toward filling many of the narrative gaps that were detected in the Hebrew Bible version by the targum's producers. Furthermore, in its rendering of 22:1 Pseudo-Jonathan creates a thematic link with the previous chapter where Sarah, Abraham's wife, drives Hagar and Ishmael from Abraham's camp because Sarah fears that Ishmael will be judged to be Abraham's true heir. In the context of Genesis 21 Sarah's actions are divinely sanctioned, and God in fact promises Abraham that Ishmael will produce a great nation in his own right (Genesis 21:13), since Ishmael is, after all, Abraham's son. However, it is obvious from the targumic rendering of 22:1 that the matter was not entirely solved from the perspective of Pseudo-Jonathan's producers. The narrative question they seek to answer with their narrative expansions is whether Isaac is individually meritorious enough to be Abraham's heir, rather than be an heir simply due to his parentage. By including the dispute between Abraham's two sons, and by furthermore making both Ishmael and Isaac responsible adults (Isaac's age is ambiguous in the Hebrew Bible, but it is usually assumed that he is younger than the age of responsibility), the targum creates a situation where Isaac can be a willing participant in his father's actions and thereby prove his righteousness in this episode as much as Abraham proves his. All this is achieved by creating a strong sense of thematic continuity between chapters 21 and 22, and by constructing a very coherent narrative in chapter 22. These targumic modifications to the translated narrative do not undermine the authority of Bible but rather enhance it by again structuring the narrative expansions around the one-to-one inter-linguistic rendering of the Hebrew Bible words and phrases. As mentioned above, the general structure of the Hebrew Bible is carried over into the targumic narratives, but the targums, in this case Pseudo-Jonathan, in many ways "strengthen" the Hebrew Bible narrative by answering questions that could 
very easily be asked of it in an early Jewish context. As such, it may be that the targums are not only concerned with translating individual words and phrases from Hebrew into Aramaic. Instead they may also be concerned with translating entire narratives into something that could be more easily appropriated by early Jewish audiences than just the Hebrew Bible without targumic narrative interventions (Lasair, 117-23).

\section{CONCLUSION}

The dynamic that governs the targumic translational technique is one of tension between the conservatism manifest by the one-to-one targumic shadow of the Hebrew Bible text and the concern for innovation and updating as manifest in the targumic narrative expansions and the coherence structures they create. These potentially conflicting dynamics within the targum texts embody in a very concrete way the tensions experienced by many translators both ancient and modern. To what extent should the target text represent even the syntax and phrasing of the source document? And to what extent should the source document be transformed into something that will be understandable and acceptable for the target audience? This dilemma is one that is unavoidable when discussing translation, since many translators see themselves as being between languages and cultures, striving somehow to mediate them. In the case of the producers of the targums it is evident that although they never articulated what their goals and techniques were in producing their target targumic texts, they did have a fairly clear idea of what they wanted to achieve in creating their targums; the frequency of the phenomena I have described is too high to suggest otherwise (cf. Samely's descriptions of various targumic dynamics in Interpretation). Nevertheless the variegated theories we can generate about the targums and their translation techniques can only be our theories. By virtue of the lack of evidence available to modern scholars, those who wish to study the targums must rely on the methods and concepts of modern scholarship in order to state anything meaningful about targumic literature. Methodological discussion is therefore a high priority in targum scholarship, for without it targum scholars run the risk of committing conceptual errors both in the process of establishing reliable descriptive tools, but also in the process of gathering evidence that is historically useful. It is with these things in mind that targum scholars can theorize in the absence of a clear and thoroughly articulated theory from the targums' own social and historical contexts. As such, this ancient 
theoretical vacuum is the foundation and impetus for all modern descriptions of the translational dynamics manifest in targumic literature.

\section{REFERENCES}

AUERBACH, Erich. Mimesis: The Representation of Reality in Western Literature. Translated by William Trask. Princeton: Princeton UP, 1968.

BAKER, Mona. Translation and Conflict: A Narrative Account. London, Routledge, 2006.

CLARKE, E.G., W.E. Aufrecht, J.C. Hurd, and F. Spitzer. Targum Pseudo-Jonathan of the Pentateuch: Text and Concordance. Hoboken: KTAV Publishing House, 1984.

FLESHER, Paul V.M. "The Translations of Proto-Onqelos and the Palestinian Targums." Journal of the Aramaic Bible 3 (2001): 75-100.

FRAADE, Steven D. "Rabbinic Views on the Practice of Targum, and Multilingualism in the Jewish Galilee of the Third-Sixth Centuries." The Galilee in Late Antiquity. Ed. Lee I. Levine. New York and Jerusalem: The Jewish Theological Seminary of America, 1992. 253-86.

GREENSPAHN, Frederick E. "Why Jews Translate the Bible." Biblical Interpretation in Judaism and Christianity. Ed. Isaac Kalimi and Peter Haas. New York: T \& T Clark, 2006. 179-95.

HAYWARD, C.T.R. "Inconsistencies and Contradictions in Targum PseudoJonathan: The Case of Eliezer and Nimrod." Journal of Semitic Studies 38.1 (1992): 31-55.

KIERKEGAARD, Søren. Fear and Trembling: Dialectic Lyric by Johannes de Silentio. Translated by Alastair Hannay. New York: Penguin, 1985.

KITTEL, R., et al., eds. Biblica Hebraica Stuttgartensia. Stuttgart: Deutsche Bibelgesellschaft, 1967/77.

LACOCQUE, André and Paul Ricoeur. Thinking Biblically: Exegetical and Hermeneutical Studies. Translated by David Pellauer. Chicago: University of Chicago Press, 1998.

LASAIR, Simon G.D.A. A Narratological Approach to the Pentateuch Targums. Manchester: University of Manchester PhD Dissertation, 2008.

NEUSNER, Jacob. The Mishnah: A New Translation. New Haven: Yale UP, 1988.

SAMELY, Alexander. Forms of Rabbinic Literature and Thought: An Introduction. Oxford: Oxford UP, 2007. 
---. The Interpretation of Speech in the Pentateuch Targums: A Study of Method and Presentation in Targumic Exegesis. Tübingen: J.C.B. Mohr (Paul Siebeck), 1992.

---. "Scripture's Segments and Topicality in Rabbinic Discourse and the Pentateuch Targum." Journal of the Aramaic Bible 1 (1999): 87-123.

---. "Writing in an (Almost) Classical Vein: The Art of Targum in an Aramaic Paraphrase of the Amidah." Bulletin of the John Rylands University Library of Manchester 75.3 (1993): 175-264.

SHINAN, Avigdor. “The 'Palestinian' Targums-Repetitions, Internal Unity, Contradictions." Journal of Jewish Studies 36 (1985): 72-87.

SMELIK, Willem F. "Language, Locus, and Translation between the Talmudim." Journal of the Aramaic Bible 3 (2001): 199-224.

SMELIK, Willem F. "Orality, Manuscript Reproduction, and the Targums." Paratext and Megatext as Channels of Jewish and Christian Tradition: The Textual Markers of Contextualization. Ed. A.A. den Hollander, U.B. Schmid, and W.F. Smelik. Leiden: Brill, 2003. 49-81.

SMELIK, Willem F. "The Rabbinic Reception of Early Bible Translations as Holy Writings and Oral Torah." Journal of the Aramaic Bible 1 (1999): 249-72.

SOKOLOFF, Michael. A Dictionary of Jewish Babylonian Aramaic of the Talmudic and Geonic Periods. Baltimore: The Johns Hopkins UP, 2002.

SOKOLOFF, Michael. A Dictionary of Jewish Palestinian Aramaic of the Byzantine Period, 2nd ed. Baltimore and London: The Johns Hopkins UP, 2002.

SPERBER, Alexander. The Pentateuch According to Targum Onqelos. Leiden: Brill, 1992. 